\title{
Morphometric Analysis of Axis Vertebra for Atlantoaxial Fixation in Northeastern Brazil
}

\author{
Gustavo de Souza Marques Filho, ${ }^{1}$ Letícia Leite Cavalcante, ${ }^{2}$ Ana Karoliny de Souza Gomes, ${ }^{2}$ João Pedro Maia Medeiros, ${ }^{1}$ \\ Henrique Ribeiro Pessoa Cavalcanti, ${ }^{1}$ André de Sá Braga Oliveira, ${ }^{1}$ Jalles Dantas de Lucena ${ }^{3}$
}

${ }^{1}$ Medicine Course, Federal University of Paraiba - UFPB. Departamento de Morfologia, Universidade Federal da Paraíba, João Pessoa - PB, Brazil ${ }^{2}$ Physical therapy Course, Federal University of Paraiba - UFPB. Departamento de Morfologia, Universidade Federal da Paraíba, João Pessoa, PB, Brazil

${ }^{3}$ Medicine Course, College Santa Maria (FSM), Cajazeiras, PB, Brazill

Disclose and conflicts of interest: none to be declared by all authors

\begin{abstract}
Introduction: the axis is the second cervical vertebra and differs from other vertebrae by presenting particular anatomical accidents. Variations in axis morphology in different populations have clinical importance, especially in atlantoaxial fixation, since the lack of anatomical reference may compromise surgical procedures in this region.

Purpose: to analyze the morphometry of axis vertebra and its clinical applications in Northeastern Brazil.

Methodology: fifty-eight axis vertebrae from the Human Anatomy Laboratory of the Federal University of Paraiba (UFPB) were used in this study. Morphometric analysis was performed using a digital caliper and data were statistically analyzed. The results were considered significant when $\mathrm{p}<0.05$.

Results: the mean width of the isthmus of the pars interarticularis was $9.25 \pm 1.68 \mathrm{~mm}$ and the height was $7.37 \pm 1,87 \mathrm{~mm}$. The mean height of the dens of the axis in an anterior view was $16.29 \pm 1.82 \mathrm{~mm}$ and the width was $9.41 \pm 0.86 \mathrm{~mm}$. The width of the articular face of the axis dimples was $8.27 \pm 0.88 \mathrm{~mm}$. The average anteroposterior length of the vertebral body was $15.29 \pm 2.02$ $\mathrm{mm}$, the width was $16.79 \pm 1.68$ and the height in an anterior view was $19.96 \pm 2.48 \mathrm{~mm}$. The average height of the vertebral lamina was $10.89 \pm 1.64 \mathrm{~mm}$ and the anteroposterior length was $20.33 \pm 2.13 \mathrm{~mm}$. Significant difference was observed between right and left sides of anteroposterior length $(p=0.012)$.

Conclusion: it was showed for the first time the axis morphometry in a specific population of Northeast Brazil. Morphological differences were observed in the present study and diverge from others in the literature. This data can serve as guidance for professionals who will perform atlantoaxial fixation in this region, highlighting the importance of anatomical knowledge and its variations.
\end{abstract}

Keywords: Anatomy; Axis vertebra; Second cervical vertebra.

\section{Introduction}

The morphometric study of the axis is of fundamental importance for the understanding of atlantoaxial fixation. This vertebra presents an atypical shape and both its anatomical and biomechanical properties are unique ${ }^{1}$. Among the atypical structures of $\mathrm{C} 2$, the dens of the axis has clinical implications, since it acts as an axis of rotation between the atlas and the head ${ }^{2}$. A good understanding of the exact dimensions and shapes of this bone is necessary for the evaluation of many clinical problems ${ }^{3}$.

At the moment, one of these major problems is the increase of fractures of the dens of the axis, which currently account for $15 \%$ of all cervical spine fractures ${ }^{4}$. Type II and III fractures are among the most common fractures of the dens. Both fractures and other pathological processes of the craniovertebral junction may require surgical procedures, including stabilization of the anterior craniovertebral junction, odontoid screw fixation, and transoral odontoidectomy ${ }^{5}$.
Within fixation procedures, transarticular fixation is the technique of choice for spinal instability procedures such as in atlantoaxial instability ${ }^{4}$. The direct anterior screw fixation technique has been shown to be effective in treating most dens instability fractures ${ }^{4,6}$, evidencing the clinical and surgical importance of this anatomic region of the cervical spine.

Therefore, the purpose of this study is to analyze the morphometry of axis vertebra and its clinical implications in a specific population in Northeastern Brazil.

\section{Material and Methods}

Fifty-eight (58) dry axis vertebrae (C2) were analyzed, regardless of gender and age. The specimens were obtained at the Laboratory of Human Anatomy of the Federal University of Paraiba (UFPB), located in Northeastern Brazil. Vertebrae with important degradation, pathological or with infantile conformation were excluded from the study, once they made their specific analysis impossible. 
Ten morphometric parameters were collected through a digital caliper with $0.01 \mathrm{~mm}$ precision (Eccofer ${ }^{\circledR}$, João Pessoa, Paraiba, Brazil) (Figure 1). The WPI, HPI, HVL and LVL measurements were measured bilaterally and the others had single measurement collection, because they did not present laterality. These quantitative measurements performed in the study were based on morphometric parameters of greatest importance for atlantoaxial fixation, according to the main existing surgical approaches addressed in the study by Morales et al, $2018^{4}$.

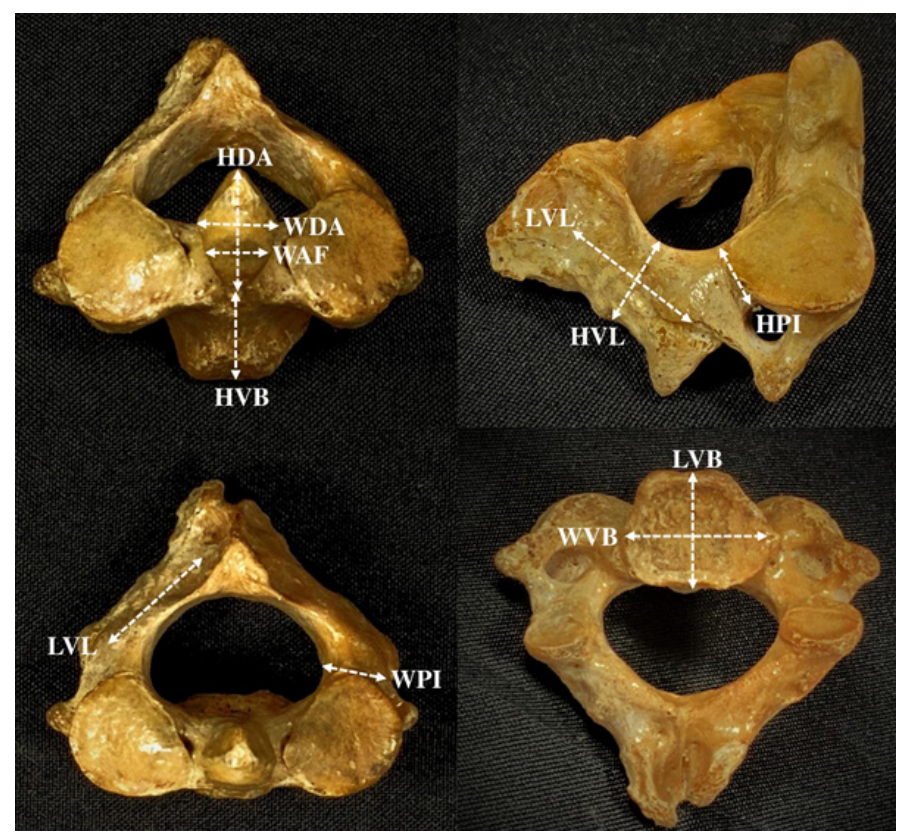

Figure 1. Axis morphometric parameters used for data collection. WPI - Distance between the lateral and medial margin of the isthmus of the pars interarticularis at the level of its narrowest point. HPI - Distance between the upper and lower margin of the isthmus of the pars interarticularis at the level of its narrowest point. HDA - Vertical distance between the junction of the odontoid process with the body of the $\mathrm{C} 2$ vertebra on its anterior face and the upper free margin of the odontoid process. WDA - Horizontal distance between the two lateral margins of the odontoid process of $\mathrm{C} 2$ at the level of half of the articular facet, by its anterior face. WAF - Distance between the two lateral margins of the articular facet of the C2 odontoid process, at the level of its midpoint. LVB - Distance between the anterior and posterior margins of the vertebral body of $\mathrm{C} 2$ at the level of the median line, on the lower face. WVB - Distance between the two lateral margins of the vertebral body of C2, by its lower face. HVB - Distance between the lower margin of the vertebral body of $\mathrm{C} 2$ on its anterior face and the junction of the upper margin of the vertebral body of $\mathrm{C} 2$ with the odontoid process. HVL - Distance between the upper and lower margin of the C2 blade at the level of its midpoint. LVL - Distance between the anterior and posterior margins of the $\mathrm{C} 2$ blade.

The 2016 version of Word was used to record measurements and descriptions. For data analysis, IBM SPSS version 26 was used to verify the normal distribution of the data, the mean, maximum and minimum values. Parametric or non-parametric tests were applied to evaluate the difference between the right and left sides of the morphometric parameters analyzed. The results were considered significant when $\mathrm{p}<0.05$.

\section{Results}

The morphometric analysis of this study is shown in Table 1. The WPI measurement had a mean on the right side of $9.37 \pm 1.69 \mathrm{~mm}$, while on the left side it was $9.67 \pm 1.67 \mathrm{~mm}$. The HPI on the right side had a mean of $7.23 \pm 2.05 \mathrm{~mm}$, and $7.52 \pm 1.69 \mathrm{~mm}$ on the left side, with no significant differences between sides.

When looking at the measurements related to the dens of the axis, the HDA had a mean of $16.29 \pm 1.82$ $\mathrm{mm}$, the WDA was $9.41 \pm 0.86 \mathrm{~mm}$, while the WAF had a mean of $8.27 \pm 0.88 \mathrm{~mm}$. Looking at the vertebral body dimensions, we found an average for the LVB of $15.29 \pm 2.02 \mathrm{~mm}$, for the WVB of $16.79 \pm 1.68 \mathrm{~mm}$, while the HVB was $19.96 \pm 2.48 \mathrm{~mm}$.

Finally, when studying the measurements related to the vertebral laminae bilaterally, we found a mean for HVL on the right of $10.92 \pm 1.64 \mathrm{~mm}$ and on the left of $10.86 \pm 1.63 \mathrm{~mm}$, with no significant differences between the sides. Analyzing the LVL bilaterally, we found a mean of $20.55 \pm 2.14 \mathrm{~mm}$ on the right and $20.10 \pm 2.12 \mathrm{~mm}$ on the left. Significant differences were found between the sides in this measurement $(p=0.012)$.

Table 1. Morphometric analysis of the axis vertebra $(n=58)$

\begin{tabular}{|c|c|c|c|c|c|c|}
\hline \multicolumn{2}{|c|}{ Variables } & \multirow{2}{*}{$\begin{array}{c}\begin{array}{c}\text { Mean } \\
(\mathrm{mm})\end{array} \\
9.37\end{array}$} & \multirow{2}{*}{$\begin{array}{c}\begin{array}{c}\text { Standard } \\
\text { Deviation } \\
(\mathbf{m m})\end{array} \\
1.69\end{array}$} & \multirow{2}{*}{$\begin{array}{c}\begin{array}{c}\text { Maximum } \\
\text { Value } \\
(\mathbf{m m})\end{array} \\
12.8\end{array}$} & \multirow{2}{*}{$\begin{array}{c}\begin{array}{c}\text { Minimum } \\
\text { Value } \\
(\mathbf{m m})\end{array} \\
6.5\end{array}$} & \multirow{3}{*}{$\begin{array}{c}\text { p-value } \\
.096\end{array}$} \\
\hline \multirow{2}{*}{ WPI } & $\mathrm{R}$ & & & & & \\
\hline & L & 9.67 & 1.67 & 15.8 & 6.2 & \\
\hline \multirow{2}{*}{$\mathrm{HPI}$} & $\mathrm{R}$ & 7.23 & 2.05 & 12.2 & 2.2 & \multirow{2}{*}{.255} \\
\hline & L & 7.52 & 1.69 & 11.4 & 1.7 & \\
\hline \multicolumn{2}{|c|}{ HDA } & 16.29 & 1.82 & 21.6 & 13.5 & \\
\hline \multicolumn{2}{|c|}{ WDA } & 9.41 & 0.86 & 11.3 & 7.7 & \\
\hline \multicolumn{2}{|c|}{ WAF } & 8.27 & 0.88 & 10.3 & 6.1 & \\
\hline \multicolumn{2}{|c|}{ LVB } & 15.29 & 2.02 & 19.2 & 9.7 & \\
\hline \multicolumn{2}{|c|}{ WVB } & 16.79 & 1.68 & 21.8 & 14.2 & \\
\hline \multicolumn{2}{|c|}{ HVB } & 19.96 & 2.48 & 25.2 & 12.1 & \\
\hline \multirow{2}{*}{ HVL } & $\mathrm{R}$ & 10.92 & 1.64 & 16.2 & 7.0 & \multirow{2}{*}{.605} \\
\hline & L & 10.86 & 1.63 & 16.2 & 7.1 & \\
\hline \multirow{2}{*}{ LVL } & $\mathrm{R}$ & 20.55 & 2.14 & 24.9 & 14.8 & \multirow{2}{*}{.012} \\
\hline & L & 20.10 & 2.12 & 24.9 & 15.1 & \\
\hline
\end{tabular}

WPI - Width of the pars interarticularis; HPI - Height of the pars interarticularis; HDA - Height of the dens of the axis; WDA - Width of the dens of the axis; WAF - Width of the articular facet of the dens of the axis; LVB - Anterior-posterior length of the vertebral body; WVB - Width of the vertebral body; HVB - Height of the vertebral body; HVL - Height of the vertebral lamina; LVL - Anteriorposterior length of the vertebral lamina. R - Right; L - Left.

\section{Discussion:}

Anatomical knowledge of the structures of the axis vertebra is of fundamental importance to understand how atlantoaxial fixation works and to achieve success in surgical procedures involving this region. In this study, there were some morphometric variations of the structures studied when compared to other studies in the area (Table 2). 
Table 2. Comparison of morphometric parameters of the axis vertebra between studies (values in $\mathrm{mm} \pm \mathrm{DP}$ )

\begin{tabular}{|c|c|c|c|c|c|c|c|c|c|c|c|c|c|c|}
\hline & \multicolumn{2}{|c|}{ WPI } & \multicolumn{2}{|c|}{ HPI } & \multirow{2}{*}{ HDA } & \multirow{2}{*}{ WDA } & \multirow{2}{*}{ WAF } & \multirow{2}{*}{ LVB } & \multirow{2}{*}{ WVB } & \multirow{2}{*}{ HVB } & \multicolumn{2}{|c|}{ HVL } & \multicolumn{2}{|c|}{ LVL } \\
\hline & $\mathbf{R}$ & $\mathbf{L}$ & $\mathbf{R}$ & $\mathbf{L}$ & & & & & & & $\mathbf{R}$ & $\mathbf{L}$ & $\mathbf{R}$ & $\mathbf{L}$ \\
\hline $\begin{array}{l}\text { Present study } \\
\text { (2021), Brazil } \\
\text { (58 axis) }\end{array}$ & $\begin{array}{c}9.37 \pm \\
1.69\end{array}$ & $\begin{array}{l}9.67 \pm \\
1.67\end{array}$ & $\begin{array}{l}7.23 \pm \\
2.05\end{array}$ & $\begin{array}{c}7.52 \pm \\
1.69\end{array}$ & $\begin{array}{c}16.29 \pm \\
1.82\end{array}$ & $\begin{array}{l}9.41 \pm \\
0.86\end{array}$ & $\begin{array}{l}8.27 \pm \\
0.88\end{array}$ & $\begin{array}{l}15.29 \pm \\
2.02\end{array}$ & $\begin{array}{c}16.79 \pm \\
1.68\end{array}$ & $\begin{array}{l}19.96 \pm \\
2.48\end{array}$ & $\begin{array}{c}10.92 \pm \\
1.64\end{array}$ & $\begin{array}{c}10.86 \pm \\
1.63\end{array}$ & $\begin{array}{c}20.55 \pm \\
2.14\end{array}$ & $\begin{array}{l}20.10 \pm \\
2.12\end{array}$ \\
\hline $\begin{array}{l}\text { Lalit et al. (2020), } \\
\text { North Indians ( } 60 \\
\text { axis) }\end{array}$ & & & & & $\begin{array}{c}16.36 \pm \\
1.68\end{array}$ & $\begin{array}{c}9.85 \pm \\
1.08\end{array}$ & $\begin{array}{l}7.89 \pm \\
1.15\end{array}$ & $\begin{array}{c}15.10 \pm \\
1.56\end{array}$ & $\begin{array}{c}15.83 \pm \\
2.12\end{array}$ & $\begin{array}{l}19.28 \\
\pm 2.24\end{array}$ & & & & \\
\hline $\begin{array}{l}\text { Teo et al. (2017), } \\
\text { USA ( } 5 \text { axis) }\end{array}$ & & & & & $\begin{array}{c}17.8 \pm \\
1.0\end{array}$ & $\begin{array}{c}11.5 \pm \\
0.8\end{array}$ & & & $\begin{array}{c}18.2 \pm \\
1.6\end{array}$ & $\begin{array}{c}26.2 \pm \\
1.4\end{array}$ & & & & \\
\hline $\begin{array}{l}\text { Mukesh Singla et } \\
\text { al. }(2015) \text {, } \\
\text { India ( } 30 \text { axis) }\end{array}$ & $\begin{array}{c}9.6 \pm \\
2.4\end{array}$ & $\begin{array}{c}9.5 \pm \\
2.2\end{array}$ & & & $\begin{array}{c}14.66 \pm \\
1.37\end{array}$ & $\begin{array}{l}9.32 \pm \\
1.05\end{array}$ & & $\begin{array}{c}15.42 \pm \\
1.78\end{array}$ & $\begin{array}{l}17.7 \pm \\
2.22\end{array}$ & $\begin{array}{c}19.67 \pm \\
1.81\end{array}$ & & & & \\
\hline $\begin{array}{l}\text { Morales-Avalos et } \\
\text { al. (2012), Mexico } \\
\left(576 \text { axis) }{ }^{4}\right.\end{array}$ & \multicolumn{2}{|c|}{$\begin{array}{c}\text { (average) } \\
8.69 \pm 2.11\end{array}$} & \multicolumn{2}{|c|}{$\begin{array}{c}\text { (average) } \\
10.82 \pm 1.89\end{array}$} & $\begin{array}{c}16.90 \pm \\
2.99\end{array}$ & $\begin{array}{l}9.99 \pm \\
0.80\end{array}$ & $\begin{array}{l}8.44 \pm \\
1.04\end{array}$ & $\begin{array}{c}15.11 \pm \\
1.88\end{array}$ & $\begin{array}{l}17.93 \pm \\
2.22\end{array}$ & $\begin{array}{l}18.54 \pm \\
2.38\end{array}$ & \multicolumn{2}{|c|}{$\begin{array}{l}\text { (average) } \\
11.53 \pm 1.39\end{array}$} & \multicolumn{2}{|c|}{$\begin{array}{c}\text { (average) } \\
6.10 \pm 1.44\end{array}$} \\
\hline $\begin{array}{l}\text { Gosavi and } \\
\text { Swamy et al. } \\
(2012) \text {, India } \\
(100 \text { axis })^{2}\end{array}$ & & & & & $\begin{array}{c}14.86 \pm \\
1.54\end{array}$ & $\begin{array}{l}9.28 \pm \\
1.07\end{array}$ & & $\begin{array}{c}14.77 \pm \\
1.73\end{array}$ & $\begin{array}{c}15.99 \pm \\
2.12\end{array}$ & $\begin{array}{c}20.49 \pm \\
2.25\end{array}$ & $\begin{array}{c}13.09 \pm \\
2.99\end{array}$ & $\begin{array}{c}7.38 \pm \\
3.16\end{array}$ & $\begin{array}{c}16.38 \pm \\
1.97\end{array}$ & $\begin{array}{l}13.30 \pm \\
3.19\end{array}$ \\
\hline $\begin{array}{l}\text { Naderi et al. } \\
(2006) \text {, Turkey } \\
(80 \text { axis) })^{5}\end{array}$ & & & & & $\begin{array}{c}15.5 \pm \\
1.8\end{array}$ & $\begin{array}{c}10.5 \pm \\
0.9\end{array}$ & $\begin{array}{c}8.8 \pm \\
1.2\end{array}$ & $\begin{array}{c}15.8 \pm \\
1.7\end{array}$ & $\begin{array}{c}18.1 \pm \\
1.8\end{array}$ & $\begin{array}{c}23.2 \pm \\
2.4\end{array}$ & & & & \\
\hline $\begin{array}{l}\text { Sengul et al. } \\
(2006) \text {, Turkey } \\
(40 \text { axis })^{8}\end{array}$ & $\begin{array}{l}9.6 \pm \\
2.4\end{array}$ & $\begin{array}{c}9.5 \pm \\
2.2\end{array}$ & & & $\begin{array}{c}14.5 \pm \\
2.3\end{array}$ & $\begin{array}{c}11.02 \pm \\
1.8\end{array}$ & & & & $\begin{array}{c}22.1 \pm \\
2.6\end{array}$ & & & & \\
\hline $\begin{array}{l}\text { Xu et al. (1995), } \\
\text { USA (50 axis)10 }\end{array}$ & $\begin{array}{r}\text { (ave } \\
\text { me } \\
8.6 \\
\text { (ave } \\
\text { fem } \\
7.9\end{array}$ & $\begin{array}{l}\text { age/ } \\
\text { e) } \\
1.4 \\
\text { age/ } \\
\text { ale) } \\
1.1\end{array}$ & $\begin{array}{r}\text { (ave } \\
\text { ma } \\
7.7 \\
\text { (ave } \\
\text { fem } \\
6.9\end{array}$ & & $\begin{array}{c}15.1 \pm \\
1.7\end{array}$ & $\begin{array}{c}9.8 \pm \\
0.9\end{array}$ & & $\begin{array}{c}\text { (male) } \\
16.1 \pm 1.5 \\
\text { (female) } \\
15.0 \pm 1.7\end{array}$ & $\begin{array}{c}18.9 \pm \\
2.3\end{array}$ & $\begin{array}{c}\text { (male) } \\
21.1 \pm 1.7 \\
\text { (female) } \\
19.5 \pm 1.7\end{array}$ & & & & \\
\hline $\begin{array}{l}\text { Doherty et al. } \\
\text { (1994), Houston, } \\
\text { Texas (51 axis) }\end{array}$ & & & & & $\begin{array}{c}16.6 \pm \\
1.9\end{array}$ & $\begin{array}{c}10.8 \pm \\
1.0\end{array}$ & & $\begin{array}{c}16.6 \pm \\
1.6\end{array}$ & $\begin{array}{c}18.7 \pm \\
1.8\end{array}$ & $\begin{array}{c}23.3 \pm \\
1.9\end{array}$ & & & & \\
\hline
\end{tabular}

WPI - Width of the pars interarticularis; HPI - Height of the pars interarticularis; HDA - Height of the dens of the axis; WDA - Width of the dens of the axis; WAF - Width of the articular facet of the dens of the axis; LVB - Anterior-posterior length of the vertebral body; WVB - Width of the vertebral body; HVB - Height of the vertebral body; HVL - Height of the vertebral lamina; LVL - Anterior-posterior length of the vertebral lamina. R - Right; L - Left.

The pars interarticularis is a structure located posterior to the articular process and medial to the transverse foramen of $\mathrm{C} 2$. It is the focus of many fixation procedures. Mandel et al. ${ }^{11}$ determines that screw placement in the pars interarticularis of the axis is of great complexity if its minimum diameter is less than $5 \mathrm{~mm}^{4}$. Identifying the dimensions of the pars interarticularis can reduce the risks of laceration of the dura mater, injury to nerve structures, and injury to the vertebral artery during the placement of these screws12. Given this perspective, the present study observed values of HPI similar to those of americans ${ }^{10}$, but lower than mexicans ${ }^{4}$. Maybe, in this population, a larger area for screw placement could facilitate procedures in this region.

In addition to the pars interarticularis of $\mathrm{C} 2$, the dens of the axis is a structure that has a large surgical field. Odontoidectomy procedures can be performed using a transoral route or less commonly using a posterolateral approach. Regardless of the approach used for odontoidectomy, some anatomical data can help the surgeon during surgery.,9 Our study did not have major differences when compared to other populations in the world (Table 2). It is worth noting that the study by Teo et al, $2017^{1}$ showed the highest values for the approached dimensions of the dens of the axis, a fact that may be linked to the form of data collection, as it was the only study to use CT scans instead of cadaveric specimens. In addition, that study has only 5 specimens analyzed, differing from the others with a larger number of specimens.

The body of the second cervical vertebra and its dens has been the focus of a variety of spinal surgical procedures, such as anterior atlantoaxial fixation, anterior occipitocervical fixation, anterior odontoid screw fixation, odontoidectomy, and other surgical procedures ${ }^{5,9}$. Therefore, anatomical knowledge of the dimensions of the vertebral body, such as its 
anteroposterior length (LVB), height (HVB), and width (WVB), is of fundamental importance. These series of axis vertebrae measurements can be taken into consideration during anterior fixation of the $\mathrm{C} 2$ body using screws to determine the length of the screw used $^{5}$. An American study by Teo et al. (2017) ${ }^{1}$ showed a higher LVH value $(26.2 \pm 1.4 \mathrm{~mm})$ when compared to other studies, a fact that may be linked to the form of CT scan data collection or the number of samples or some regional anatomical variation. Together, these results suggests that variations related to the vertebral body would influence the choice of screw dimensions to be used in procedures involving this region.

Vertebral laminae are also important structures during surgical procedures, such as laminectomy, which is widely used to gain access to internal structures of the vertebral canal. The present study showed no differences bilaterally in the HVL mean. The study by Gosavi and Swamy et al. ${ }^{2}$ showed that the length, thickness and height of the vertebral laminae were higher on the right side compared to the left side and this difference was statistically significant. The study with Mexicans ${ }^{4}$ showed lower LVL values than other studies. They also used the same morphometric parameters and cadaveric specimens. This difference may be related to some phenotypic variation in the Mexican region or to some anatomical abnormality in the sample or some characteristic of the age group of the sample ${ }^{4}$. Significant differences were found in the present study when comparing the right and left sides values of $L V L$, with $p=0.012$, which may be a specific characteristic of the population studied in the present study. The analysis of these morphometric parameters of the vertebral lamina may give more safety to the surgeon during procedures such as laminectomy, reducing the risk of damaging adjacent structures.

\section{Conclusion}

Given the analysis performed in this study, we could perceive differences in axis morphology around the world, including Brazil. Knowledge of axis anatomy could be crucial for the success of procedures in Northeastern Brazil. We hope that the data discussed can guide professionals who will handle this region, facilitating and reducing the chances of unforeseen events during the surgical interventions.

\section{References}

1. Teo EC, Haiblikova S, Winkelstein B, Welch W, Holsgrove T, Cazzola D. Morphometric Analysis of Human Second Cervical Vertebrae (Axis). J Spine 2017;6(6):1-7.

2. Gosavi S, Swamy V. Morphometric anatomy of the axis vertebra. Eur J Anat. 2012;16(2):98-103

3. Doherty BJ, Heggeness MH. Quantitative anatomy of the second cervical vertebra. Spine (Phila Pa 1976). 1995;20(5):513-517.

4. Morales-Avalos R, Re Elizondo-Omaña RE, Vílchez-Cavazos $F$, et al. Vertebral fixation with a transpedicular approach. Relevance of anatomical and imaging studies. Acta Ortop Mex 2012;26(6):402-411. 5. Naderi S, Arman C, Güvençer M, et al. Morphometric analysis of the $\mathrm{C} 2$ body and the odontoid process. Turk Neurosurg 2016:16(1):1418.

6. Jeanneret B, Magerl F. Primary posterior fusion C1/2 in odontoid frac tures: indications, technique, and results of transarticular screw fixation. J Spinal Disord 1992;5(4):464-475.

7. Singla M, Goel P, Ansari MS, Ravi KS, Khare S. Morphometric analysis of axis and its clinical significance-an anatomical study of Indian human axis vertebrae. J Clin Diagn Res 2015;9:AC4-9.

8. Sengul G, Kodiglu HH. Morphometric anatomy of atlas and axis vertebra. Turkish neurosurgery 2006;16(2):69-76.

9. Lalit M, Piplani S, Kullar JS, Mahajan A. Morphometric Analysis of Body and Odontoid Process of Axis Vertebrae in North Indians: An Anatomical Perspective. Ital J Anat Embryol 2020;124(3):475-486. 10. Xu R, Nadaud MC, Ebraheim NA, Yeasting RA. Morphology of the second cervical vertebra and the posterior projection of the C2 pedicle axis. Spine 1994;20(3):259-263.

11. Mandel IM, Kambach BJ, Petersilge CA, Johnstone B, Yoo JU. Morphologic considerations of C2 isthmus dimensions for the placement of transarticular screws. Spine (Phila Pa 1976) 2000;25(12):1542-1547.

12. Carvalho MF, Pereira CU, Leite RF, Monteiro JTS. Análise Morfométrica do axis e suas relações com a fixação transarticular C1-C2 por meio de parafusos. J Bras Neurocirurg 2007;18(3):30-34.
Received: November 23, 2018

Accepted: January 28, 2020
Corresponding author

Jalles Dantas de Lucena

e-mail: jallesdantas@gmail.com 